\title{
of the GiLded Age
}

\section{CONTRIBUTORS}

\section{EDITORs' NoTE, APRIL 2018}

\section{ARTICLES}

Theory and History of Financial Crises: Explaining the Panic of 1873 Christoph Nitschke

Defining the Public Good in the U.S. Gilded Age, 1883-1898: "Freedom of Contract" versus "Internal Police"

in the Tortured History of Employment Law and Regulation

\section{Mary O. Furner}

Emory Johnson and the Rise of Economic Expertise in the Progressive State, 1898-1913

Drew VandeCreek

"A Grim Memorial of Its Thorough Work of Devastation and Desolation": Race and Memory in the Aftermath

of the 1893 Sea Island Storm

Robert D. Bland

Health Activism from the Bottom Up: Progressive Era Immigrant Chicagoans' Views on Germ Theory,

Environmental Health, and Class Inequality

Shana Bernstein

Wobbly Vitalism: Bergson, Sorel, and the Interpretation of Revolutionary Syndicalism in the United States, 1905-1915

Jeffrey Scott Brown

The Ku Klux Klan, Labor, and the White Working Class during the 1920 s

Thomas R. Pegram

\section{Classic BOOK REFleCtion}

Robert Wiebe's The Search for Order, Fifty Years On

lan Tyrrell

BоOK ReVIEIVS

Published by the Society for Historians of the Gilded Age and Progressive Era www.jgape.org
CAMBRIDGE UNIVERSITY PRESS

Additional sponsors: Illinois State University, the University of Illinois at Chicago,

Loyola University Chicago, and Kent State University 
Editors: Benjamin H. Johnson, Loyola University Chicago

Robert D. Johnston, University of Illinois at Chicago

Boyd Cothran, York University

C. Joseph Genetin-Pilawa, George Mason University

Book Review Editor: Elaine Frantz Parsons, Kent State University

Book Review Editor's Assistant: Michele Curran Cornell, Kent State University

Editorial Assistant: Timothy Herbert, University of Illinois at Chicago

Online Editor: Christopher McKnight Nichols, Oregon State University

Founding Editor, 2000-2003: Maureen A. Flanagan, Michigan State University Editor, 2004-2014: Alan Lessoff, Illinois State University

\section{Editorial Board}

Cara Caddoo

Indiana University

Christopher Cantwell

University of Wisconsin, Milwaukee

Rosanne Currarino

Queen's University

Greg Downs

University of California-Davis

Cristina Groeger

Lake Forest College

LaShawn Harris

Michigan State University

Sonia Hernandez

Texas A \& M University

Doug Kiel

Northwestern University
Michael Lansing

Augsburg University

Beth Lew-Williams

Princeton University

Rebecca Tinio McKenna

University of Notre Dame

Michele Mitchell

New York University

Kevin Murphy

University of Minnesota, Twin Cities

Julia $\bigcirc$ tt

The New School

K. Stephen Prince

University of South Florida

Daniel Wortel-London

New York University

Hal Moore, ex officio

Cambridge University Press

Articles appearing in this journal are abstracted and indexed in America: History and Life, Historical Abstracts, Scopus, and in the Thompson Reuters Social Sciences Citation Index, Arts \&o Humanities Citation Index, and Current Contents: Social and Behavioral Sciences.

Instructions appear at the end of this issue for accessing the online edition at Cambridge Journals Online, http://journals.cambridge.org/jga. All content is available from Volume 1 , Number 1 through the present. The journal is also archived in JSTOR, www.jstor.org, with issues older than five years available to subscribers of JSTOR's Arts \& Sciences V Collection.

Change of Address: Contact alwood@ilstu.edu or go to http://journals.cambridge.org/jga 
The Journal of the Gilded Age and Progressive Era (1537-7814) is a peer-reviewed journal published quarterly in January, April, July, and October by Cambridge University Press, One Liberty Plaza, New York, NY 10006 / Cambridge University Press, Journals Fulfillment Department, UPH, Shaftesbury Road, Cambridge CB2 8BS, U.K., for the Society for Historians of the Gilded Age and Progressive Era (SHGAPE). It publishes original scholarly essays covering the period 1865 to 1920 and reviews scholarly books on that time period.

Publishing, Advertising, and Subscription Offices: Cambridge University Press, One Liberty Plaza, New York, NY 10006, U.S.A. (for U.S.A., Canada, and Mexico); or Cambridge University Press, Journals Fulfillment Department, UPH, Shaftesbury Road, Cambridge CB2 8BS, U.K. (for U.K. and elsewhere).

Annual institutional subscription rates for Volume 17, 2018, are $\$ 198.00$ in the U.S.A., Mexico, and Canada and $£ 129.00$ elsewhere for print and electronic subscriptions; and $\$ 155.00$ in the U.S.A., Mexico, and Canada and $£ 97.00$ elsewhere for electronic subscriptions only. The rate for regular members of the Society for Historians of the Gilded Age and Progressive Era (SHGAPE) is $£ / \$ 45.00$ for print and electronic subscriptions. The rate for sustaining members of the Society for Historians of the Gilded Age and Progressive Era (SHGAPE) is $£ / \$ 45.00$ for print and electronic subscriptions. The rate for student members is $\mathfrak{f} \$ 18$ for print and electronic subscriptions. The rate for lifetime membership in SHGAPE is $\$ 500.00$ for print and electronic subscriptions. Single part: $\$ 57.00$ in the U.S. A., Mexico, and Canada and $£ 37.00$ elsewhere. Prices include postage and insurance. Journal of the Gilded Age and Progressive Era and all other Cambridge journals can be found at http://journals.cambridge.org/.

Individual subscriptions include a membership in SHGAPE, which in addition to publishing this journal offers book and article prizes, sponsors sessions at the annual meetings of the American Historical Association and Organization of American Historians, and edits H-SHGAPE, an H-Net discussion list.

For back issues, please contact Periodicals Service Company, 11 Main Street, Germantown, NY 12526; email: psc@periodicals.com

Manuscripts should be submitted electronically in MS Word or RTF format to the co-editor, Robert D. Johnston, at jgape@uic.edu. Before submitting any manuscript, please consult http://journals.cambridge.org/jga for details on correct format and citation style. Information may also be obtained via email at jgape@uic.edu.

(C) Society for Historians of the Gilded Age and Progressive Era (SHGAPE) 2018. All rights reserved. No part of this publication may be reproduced in any form or by any means, photocopying, electronic, or otherwise, without permission in writing from Cambridge University Press. Policies, request forms, and contacts are available at: http://www.cambridge.org/ rights/permissions/permission.htm.

Permission to copy (for users in the U.S.A.) is available from the Copyright Clearance Center (CCC),www.copyright.com, email: info@copyright.com.

Forwarding and return postage guaranteed, address correction requested. Postmaster: Send address changes in the U.S.A. and Canada to Journal of the Gilded Age and Progressive Era, Cambridge University Press, Journals Fulfillment Dept., One Liberty Plaza, New York, NY 10006. Send address changes elsewhere to Journal of the Gilded Age and Progressive Era, Cambridge University Press, Journals Fulfillment Department, UPH, Shaftesbury Road, Cambridge CB2 8BS, U.K. 


\section{The Journal of the Gilded Age and Progressive Era \\ Volume 17 • Number 2 - April 2018}

\section{CONTENTS}

\section{CONTRIBUTORS}

\section{ARTICLES}

Christoph Nitschke Theory and History of Financial Crises: Explaining the Panic of 1873

Mary O. Furner Defining the Public Good in the U.S. Gilded Age, 1883-1898: "Freedom of Contract" versus "Internal Police" in the Tortured History of Employment Law and Regulation

DREW VANDECREEK Emory Johnson and the Rise of Economic Expertise in the Progressive State, 1898-1913

Robert D. Bland "A Grim Memorial of Its Thorough Work of Devastation and Desolation": Race and Memory in the Aftermath of the 1893 Sea Island Storm

Shana Bernstein Health Activism from the Bottom Up: Progressive Era Immigrant Chicagoans' Views on Germ Theory, Environmental Health, and Class Inequality

JEFFREY ScotT BRown Wobbly Vitalism: Bergson, Sorel, and the Interpretation of Revolutionary Syndicalism in the United States, 1905-1915

Thomas R. Pegram The Ku Klux Klan, Labor, and the White Working Class during the 1920s

\section{CLASSIC BOOK REFLECTION}

IAN TyRRELL Robert Wiebe's The Search for Order, Fifty Years On

\section{REVIEWS}

LISA McGIRR The War on Alcohol: Prohibition and the Rise of the American State (Jessica R. Pliley)

Benjamin H. Johnson Escaping the Dark, Gray City: Fear and Hope in Progressive-Era Conservation

(Mark V. Barrow, Jr.)

Ryan Dearinger The Filth of Progress: Immigrants, Americans, and the Building of Canals and Railroads in the West

(Roseanne Currarino)

Martin T. OllifF Getting Out of the Mud: The Alabama Good Roads Movement and Highway Administration, 1898-1928

(Tammy Ingram)

On the cover: Thomas Nast depicts President Grant as a friendly police chief helping Lady Liberty escape from Wall Street's ruins after the Panic of 1873. The Panic left an indelible mark on Gilded Age America, and—despite Nast's optimism—-the nation did not recover so easily. See Christoph Nitschke, "Theory and History of Financial Crises: Explaining the Panic of 1873." 
Joshua E. Kastenberg To Raise and Discipline an Army: Major General Enoch Crowder, the Judge Advocate General's Office, and the Realignment of Civil and Military Relations in World War I

(Stephen K. Stein)

Rebecca Tinio McKenna American Imperial Pastoral: The Architecture of U.S.

Colonialism in the Philippines

(Sarah Steinbock-Pratt)

CAROle Emberton ANd Bruce E. BAKER Remembering Reconstruction: Struggles Over the Meaning of America's Most Turbulent Era

(Nina Silber)

Christi M. SмIth Reparation and Reconciliation: The Rise and Fall of Integrated Higher Education

(Reginald K. Ellis)

BRIAN ROBERTS Blackface Nation: Race, Reform and Identity in American Popular Music, $1812-1945$

(Marvin McAllister) 